\title{
Autopsy on a dead spreading center: The Phoenix Ridge, Drake Passage, Antarctica
}

\author{
Roy Livermore British Antarctic Survey, Cambridge CB3 OET, UK \\ Juan Carlos Balanyá \\ Andrés Maldonado \\ José Miguel Martínez \\ Instituto Andaluz Ciencias de la Tierra, Universidad de Granada, 18002 Granada, Spain \\ José Rodríguez-Fernández \\ Carlos Sanz de Galdeano \\ Jesús Galindo Zaldívar _ _ Departamento de Geodinámica, Universidad de Granada, 18071 Granada, Spain

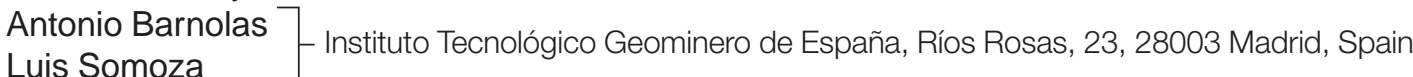 \\ Javier Hernández-Molina Facultad de Ciencias del Mar, Cádiz, Spain \\ Emma Suriñach Departamento de Geodinámica i Geofísica, Universitad de Barcelona, 08028 Barcelona, Spain \\ César Viseras Departamento de Estratigrafía y Paleontología, Universidad de Granada, 18071 Granada, Spain
}

\begin{abstract}
New bathymetric and magnetic anomaly data from the Phoenix Ridge, Antarctica, show that extinction of all three remaining segments occurred at the time of magnetic chron C2A $(3.3 \pm 0.2 \mathrm{Ma})$, synchronous with a ridge-trench collision south of the Hero Fracture Zone. This implies that the ultimate cause of extinction was a change in plate boundary forces occasioned by this collision. Spreading rates slowed abruptly at the time of chron C4 (7.8 $\pm 0.3 \mathrm{Ma})$, probably as a result of extinction of the West Scotia Ridge, which would have led to an increase in slip rate and transpressional stress across the Shackleton Fracture Zone. Spectacular, highrelief ridges flanking the extinct spreading center, mapped for the first time using multibeam swath bathymetry, are interpreted as a consequence of a reduction in spreading rate, involving a temporary magma oversupply immediately prior to extinction.
\end{abstract}

Keywords: Drake Passage, Phoenix Ridge, Antarctic plate, spreading centers.

\section{INTRODUCTION}

Extinction of spreading and the capture of subducting microplates may have major tectonic consequences, such as the rotation of the western Transverse Ranges, California (Nicholson et al., 1994), and the rifting of New Zealand from Gondwana (Luyendyk et al., 1996). Understanding the sequence of events leading to the cessation of spreading at ridge segments approaching subduction zones is thus of great interest. In the Drake Passage, between South America and Antarctica, the last remnant of the once-extensive PhoenixAntarctic spreading center, the Phoenix Ridge, appears to have become extinct at some time during the Pliocene (Larter and Barker, 1991). As a result, a small remnant $\left(\sim 9 \times 10^{4} \mathrm{~km}^{2}\right)$ of the former Phoenix plate, confined between the Shackleton and Hero Fracture Zones (Fig. 1), has become welded to the Antarctic plate. Sediment accumulation has been prevented by the presence of the Antarctic Circumpolar Current as it is funneled into Drake Passage (Lawver et al., 1992), so that the fossil spreading axis is, uniquely, exposed to bathymetric mapping in the same way as most active spreading centers. During the 1997-1998 austral summer season, a complete segment of the Phoenix Ridge was mapped using a multibeam echo sounder fitted to the Spanish research vessel BIO Hesperides. This, together with magnetic field measurements, has provided a picture of events leading to the demise of the spreading center, and permits us to speculate about the likely causes of extinction.

\section{PHOENIX RIDGE EVOLUTION}

The Phoenix plate formed one of the major Pacific Ocean plates (Larson and Chase, 1972; Nakanishi et al., 1992), created by seafloor spreading since the Jurassic at the PacificPhoenix and Farallon-Phoenix ridges, and, latterly, the Phoenix-Antarctic Ridge. Previous work (Barker, 1982; Larter and Barker, 1991) suggests that the three remaining Phoenix Ridge segments became inactive following collisions between more southerly ridge segments and an active subduction zone to the southwest of the Hero Fracture Zone (Fig. 1). Because the Antarctic plate formed both the trailing and overriding plate in this subduction system, these ridgetrench collisions resulted in the progressive northward extinction of tectonic activity at the margin. Continued subduction at the South Shetland Trench, with oceanward retreat of the hinge of subduction, then led to the rifting and separation of a sliver of the Antarctic Peninsula margin carrying the South Shetland Islands, and the opening of the Bransfield Strait marginal basin (Maldonado et al., 1994). The cause of Phoenix
Ridge extinction has been attributed to changes in plate boundary forces occasioned by the cessation of spreading on the nearby West Scotia Ridge, giving rise to transpressive stresses across the Shackleton Fracture Zone, or by reduction in slab width following ridge-trench collision to the southwest of the Hero Fracture Zone (Barker and Austin, 1998).

On the basis of reconnaissance precision echo sounder and magnetic data, it was concluded (Larter and Barker, 1991) that three inactive segments of the Phoenix Ridge survive, which we refer to (northeast to southwest) as P1, P2, and P3. Magnetic anomaly profiles crossing $\mathrm{P} 1$ and $\mathrm{P} 3$ were interpreted to imply extinction ca. 4.5 Ma (Barker, 1982) or 3.5 Ma (Larter and Barker, 1991), following a period of declining spreading rates, although the interpretation was hampered by an absence of data over segment P2.

\section{BATHYMETRY}

Regional bathymetry derived from satellite altimetry (Smith and Sandwell, 1994) confirms this general picture (Fig. 1), showing that the central segment (P2) is separated from the others by very straight, long-lived transforms with 80 $100 \mathrm{~km}$ offsets. New swath bathymetry was obtained over P2 in 1998 using a Simrad EM12 multibeam sounder on the Spanish research vessel BIO Hesperides, along tracks spaced $10 \mathrm{~km}$ apart, and processed onboard using the MB-System software (Caress and Chayes, 1996). A map of the new data is shown in Figure 2.

Off-axis morphology of segment $\mathrm{P} 2$ is generally comparable to that of fast or intermediate rate spreading ridges, such as the East Pacific Rise or Pacific-Antarctic Ridge, dominated by linear, axis-parallel magmatic ridges and straight, sharply defined fracture zones. Abyssal hills strike perpendicular to fracture zones, except near transforms, where fabric as much as $10 \mathrm{~km}$ from the transform appears to be rotated in a clockwise 
Figure 1. Bathymetry in Drake Passage predicted using satellite altimetry (Smith and Sandwell, 1994). Dotted lines represent inactive Phoenix Ridge and West Scotia Ridge; box shows area represented by Figure 3. BS-Bransfield Strait; HFZ-Hero Fracture Zone; SCT-southern Chile Trench; SFZ-Shackleton Fracture Zone; SSTSouth Shetland Trench; WSR-West Scotia Ridge.

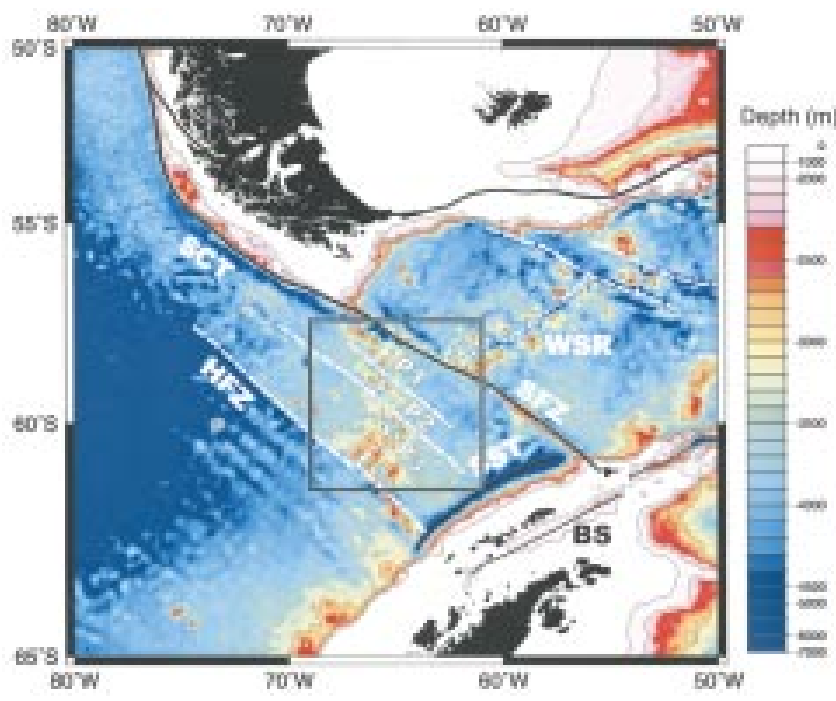

sense, suggesting transform shear. On the outside corners of $\mathrm{P} 2$, abyssal hills curve toward the direction of offset, as observed by Macario et al. (1994) at the Pacific-Antarctic Ridge.

The near-axis spreading center morphology of P2 shows very high relief, and is anomalous when compared to either fast or slow spreading

ridges elsewhere. Well-developed nodal basins occur at both ends of P2, at depths of 4000$4500 \mathrm{~m}$, and are the only areas in which any significant accumulation of sediment has occurred. Between them, the ridge crest rises to a depth of 2000 m near the segment center, forming a saddle-like structure.

\section{BATHYMETRY}

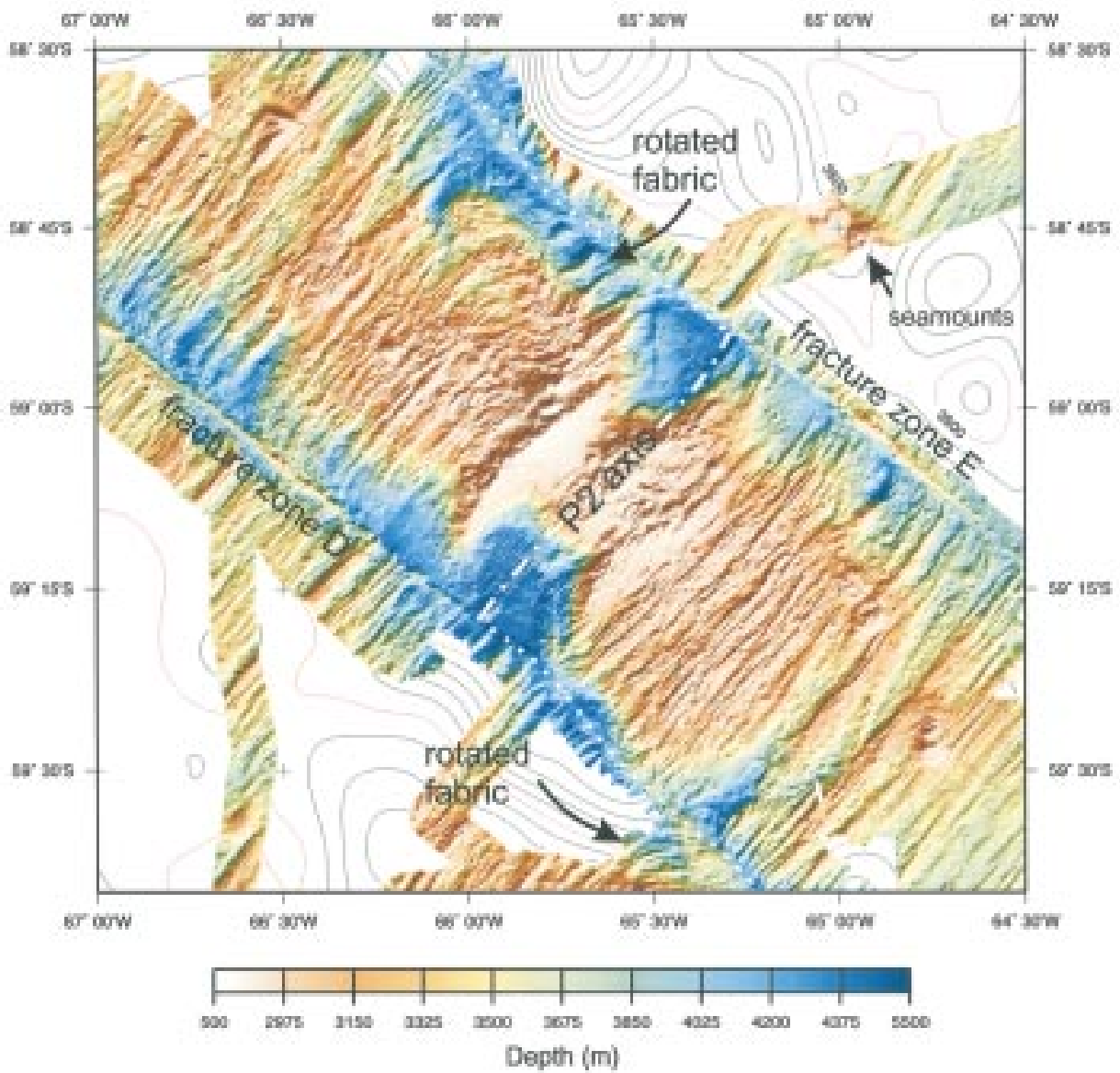

Figure 2. Bathymetry of Phoenix Ridge segment, P2, obtained using Simrad EM12 multibeam sonar. Shaded relief representation and illumination from south. Contours are depths predicted from satellite altimetry (Smith and Sandwell, 1994).

The axial region is flanked by two great ridges; that on the northwest flank rises to an unexpectedly shallow $570 \mathrm{~m}$ depth near the segment center, and that on the southeast flank is deeper than $1500 \mathrm{~m}$. The ridges are equidistant from the ridge axis, and have similar trends, suggesting that they are rifted parts of a former axial topographic high, the strike of which was rotated clockwise by $\sim 10^{\circ}$ compared to the overall trend of off-axis fabric. Toward Fracture Zone D, the northwestern ridge displays a hooked form, mimicking that of adjacent fabric on the outside corner, but on a slightly larger scale.

\section{MAGNETIC ANOMALIES}

The earliest interpretation of magnetic anomaly profiles over the Phoenix Ridge (Barker, 1982) implied extinction of segment P3 at magnetic chron C3 (ca. 4 Ma on the time scale of LaBrecque et al., 1977), following a reduction in spreading rate at about chron 3B (ca. 6 Ma on the time scale of LaBrecque et al., 1977). A more complicated model was invoked by Larter and Barker (1991), who observed differences in the axial magnetic signatures of segments P1 and P3, and also interpreted the absence of a pronounced central magnetic high in all available profiles as evidence that spreading could not have continued into the Brunhes epoch. These interpretations were handicapped by the lack of data from the central segment (P2).

Scalar magnetic field measurements were made during our survey of segment P2 using a Geometrics G-876 magnetometer with a sampling interval of $2 \mathrm{~s}$. The data were edited visually to eliminate spikes and obvious errors, and filtered using a running mean to obtain data every minute. Magnetic anomalies were calculated using the International Geomagnetic Reference Field 1995 (Barton et al., 1996), after correction for diurnal variations and magnetic disturbances using land data obtained at the Spanish magnetometric station (Torta et al., 1999) at Livingston Island $\left(62^{\circ} 39^{\prime} 4^{\prime \prime} \mathrm{S}, 60^{\circ} 23^{\prime} 41^{\prime \prime} \mathrm{W}\right)$.

Six new profiles were obtained (Fig. 3) that provide coverage of the axial region of $\mathrm{P} 2$, plus an extended profile on the former Phoenix plate. The latter correlates extremely well with synthetic anomalies computed from chron C5AC (14.1 Ma) to chron C4A (8.7 Ma) using halfspreading rates of 30-32 km/m.y. (Fig. 4), with every anomaly clearly identifiable. A small $8 \mathrm{~km}$ westward jump just after chron C5r.2 is incorporated to account for the double-peaked appearance of this anomaly, an interpretation supported by the presence of a 600 -m-high bathymetric ridge at this point. The excellent fit of the older anomalies provides a sound basis for the interpretation of younger anomalies near the ridge axis, where anomaly identification on segments P1 and P3 was previously uncertain.

In our preferred model, a reduction in halfspreading rates from 32 to $27 \mathrm{~km} / \mathrm{m}$.y. occurs 
within chron C4A (9 Ma), followed by further decreases to $16 \mathrm{~km} / \mathrm{m} . \mathrm{y}$. (eastern flank) and $24 \mathrm{~km} / \mathrm{m}$.y. (western flank) at chron C4 (7.8 Ma). Between chrons C3A and C3 (5.6 Ma), spreading slowed to $13 \mathrm{~km} / \mathrm{m} . \mathrm{y}$., and continued at this rate until extinction within chron $2 \mathrm{~A}$ at $3.3 \mathrm{Ma}$. We estimate an uncertainty of 0.2 m.y. for this date, based upon the ages of adjacent reversals. This interpretation depends upon our identification of the positive anomaly $\mathrm{C} 2 \mathrm{~A}$ directly over the axis of the median valley observed in the new bathymetric profiles (shown in Fig. 4). Profiles over the shallowest parts of the ridge axis have the smallest depths to the magnetic source, and show finer details of the anomalies, including all three peaks of anomaly C3 (C3n.1, C3n.2, and C3n.3/4) on some profiles.

Larter and Barker (1991) concluded from their magnetic anomaly modeling that segment P3 ceased spreading earlier than segment P1, following chrons C3 (3.6 Ma on the time scale of Cande and Kent 1995), and C2A (2.4 Ma), respectively, or that extremely slow spreading accompanied the final phase of P3. Their modeling was based upon the correlation of a negative anomaly in the central sequence with the relict spreading axis. Comparison with satellite-derived topography (Fig. 1) shows that more likely locations for the axes of segments P1 and P3 are directly beneath the adjacent magnetic highs, as in segment P2. Using our spreading model with minor rate changes, we find excellent fits to anomalies C3A and older over P1 and P3, and convincing fits on several profiles to anomalies C3 and C2A, demonstrating that all three sets of anomalies may be satisfied by a model in which spreading ceases during chron $2 \mathrm{~A}$, following a period of declining rates (Fig. 4).

\section{DISCUSSION: THE FINAL STAGES OF SPREADING}

The apparently abrupt extinction of the Phoenix Ridge may have occurred when slab pull traction on the Phoenix plate was reduced by the loss of $\sim 100 \mathrm{~km}$ of slab following the final ridgetrench collision to the south of Hero Fracture Zone. We note that a magnetic anomaly profile just southwest of the Hero Fracture Zone, shown by Larter and Barker (1991, their Fig. 6), includes a narrow, high-amplitude anomaly landward of identified anomaly C3. This anomaly is probably anomaly $\mathrm{C} 2 \mathrm{~A}$, dating the end of ridge-trench collision and of subduction in this compartment at

Figure 4. Modeled magnetic anomaly profiles over segments P1 (top, RRS Shackleton cruise Shack71), P2 (center, BIO Hesperides data), and P3 (bottom, R/V Conrad cruise C1503). Time scale of Cande and Kent (1995) is used, with 1-km-thick magnetized layer and upper surface corresponding to smoothed version of observed bathymetry. Spreading rates used are shown in lower parts of figures.

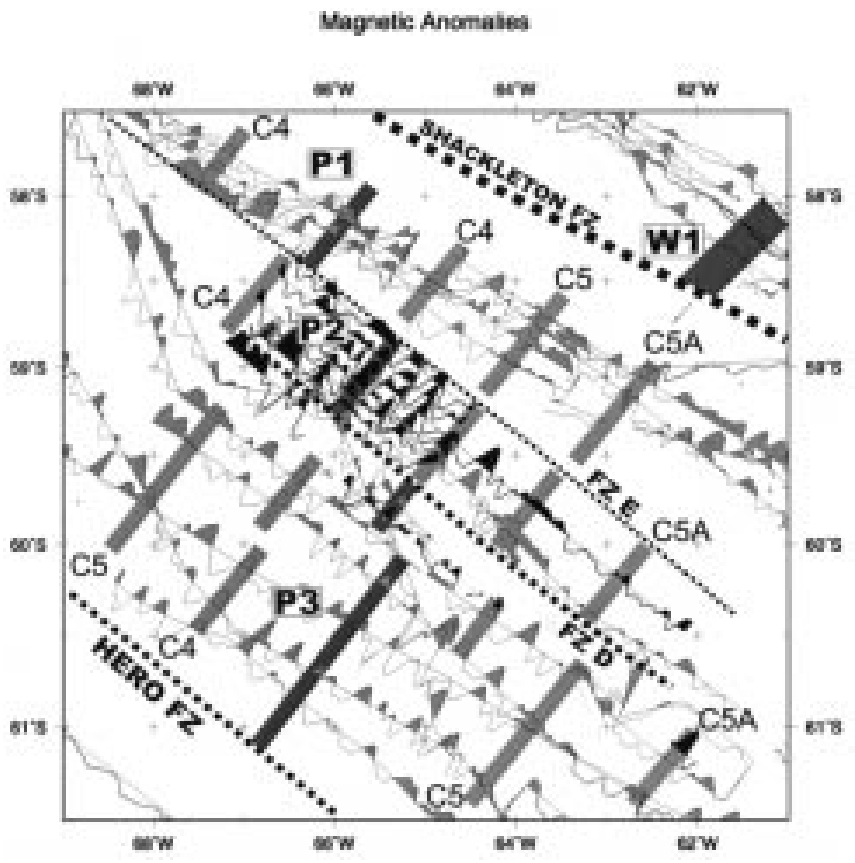

Figure 3. Selected magnetic anomaly profiles over Phoenix Ridge; positive parts of new BIO Hesperides profiles are in black, all others in gray. FZ-fracture zone.
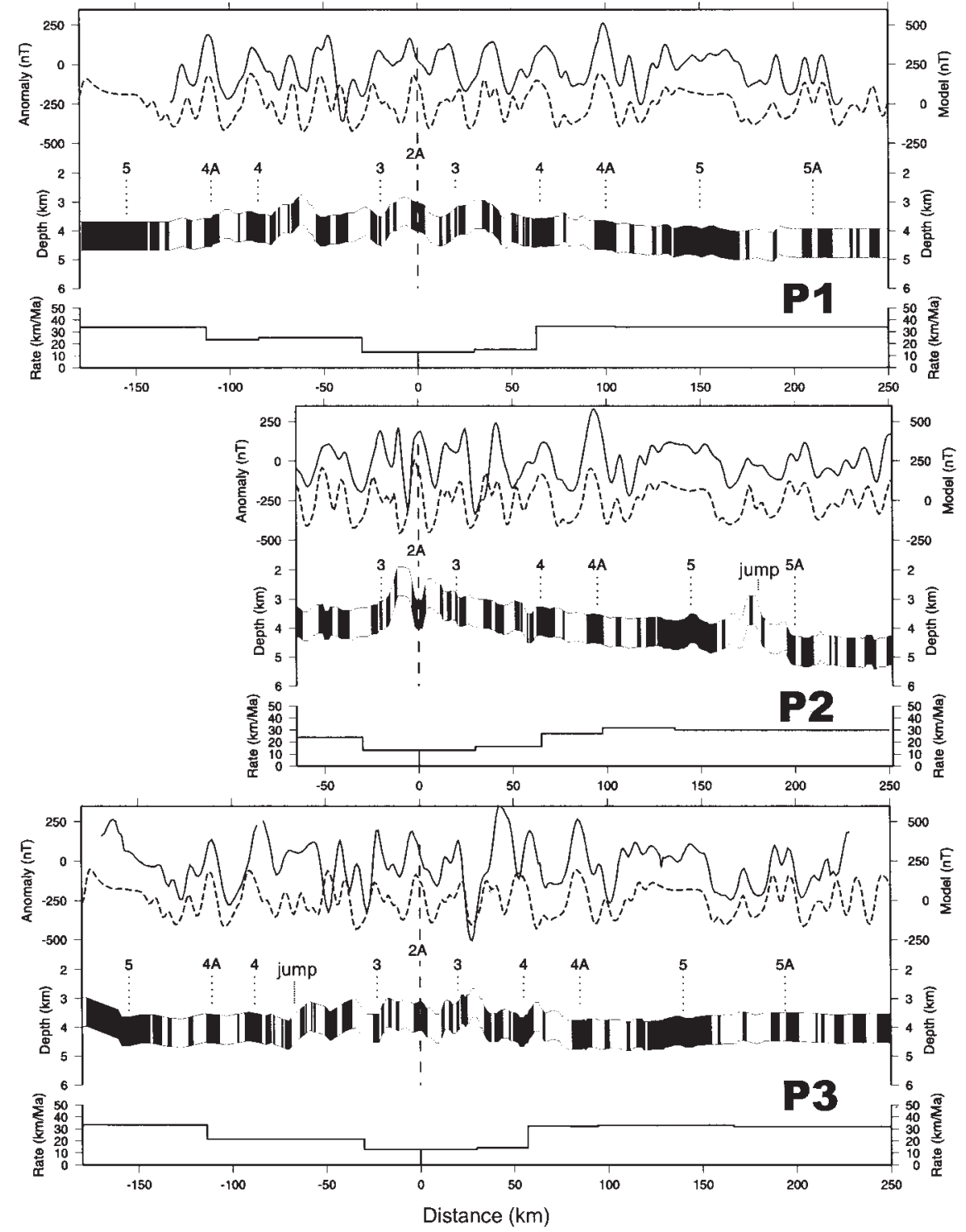
3.3 Ma, identical to the age derived here for Phoenix Ridge extinction. If this is correct, it appears that this collision, by reducing the extent of the subducting slab, may have altered the boundary forces driving the Phoenix plate to the point at which spreading was no longer possible, resulting in its fusion with the Antarctic plate.

The latter stages of spreading are characterized by decreasing rates that were probably more gradual than represented here. In all three spreading compartments, rates decline from $>30 \mathrm{~km} / \mathrm{m}$.y. prior to chron C4A (7.8 Ma) to $13 \mathrm{~km} / \mathrm{m}$.y. just before extinction. An abrupt drop at chron $\mathrm{C} 4 \mathrm{~A}$ on the western flank was followed by asymmetric spreading until chron $\mathrm{C} 4$, when rates on the eastern flank also declined. Cessation of West Scotia Ridge spreading at about chron C4 (Livermore et al., 1994; Maldonado et al., 2000) would have led to a change in relative motion on the Shackleton Fracture Zone between the enlarged Scotia plate and the Phoenix plate to the west. The result would have been an increase in both the amount of sinistral slip and of compressive stress (Larter and Barker, 1991), retarding the small Phoenix plate remnant, and reducing the rate of Phoenix-Antarctica spreading. This might explain the late changes in ridge axis and transform orientation and adjacent deformed fabric observed on fracture zones D and E in the multibeam bathymetry, and is consistent with recent evidence (Maldonado et al., 2000) that shows that shortly after the cessation of spreading on the West Scotia Ridge, there was inversion of the tectonic regime, with the development of transpressional faults along the northeast flank of the Shackleton Fracture Zone and overthrusting of Scotia crust.

The origin of the spectacular, high-relief paired ridges observed on segment $\mathrm{P} 2$ may also be in the abrupt reduction in spreading rates at about $\mathrm{C} 4$, which placed the ridge within the range in which nonmagmatic extension by crustal thinning becomes dominant (e.g., Small, 1994). This may have resulted in a temporary magma oversupply, leading to high extrusion rates and a volcanic construction comparable perhaps to Spiess Ridge on the Southwest Indian Ridge (Mitchell and Livermore, 1998). We note that the ridge on the northwest flank, on which the accretion rate fell sharply ca. 5.2 Ma (Fig. 4), is higher than that to the southeast, where the drop in rate was smaller. In like manner, the central dome could have resulted from the final emptying of the magma plumbing system immediately following cessation of spreading. Axial highs are observed at some extinct, slow-spreading ridges elsewhere, e.g., Powell basin (King et al., 1997) and Wharton basin (Hébert et al., 1999), but are by no means common. Hence, they may be indications of locally robust magma supply prior to extinction, caused by strong upwelling or higher than normal mantle temperatures.

\section{CONCLUSION}

The Phoenix Ridge expired 3.3 Ma during chron $\mathrm{C} 2 \mathrm{~A}$, following sharp drops in spreading rate at the times of chrons $\mathrm{C} 4 \mathrm{~A}(9 \mathrm{Ma})$ and $\mathrm{C} 4$ (7.8 Ma). Extinction appears to have been simultaneous on all three remaining segments of the ridge, and synchronous with the final ridgetrench collision to the southwest of the Hero Fracture Zone. This collision reduced the slab width, leading to a reduction in slab pull and, ultimately, to Phoenix Ridge extinction. These changes in spreading seem to have led to excess volcanism on one of the three remaining ridge segments, creating steep-sided volcanic ridges.

\section{ACKNOWLEDGMENTS}

We thank the captain and crew of BIO Hesperides for their support during ANTPAC97. We thank Rob Larter for discussions. Joann Stock and Tom Parsons provided valuable reviews. The Comisión Interministerial de Ciencia y Tecnología of Spain provided support for the work through the research project ANT96-1001. Figures were created using the GMT software of P. Wessel and W.M.F. Smith.

\section{REFERENCES CITED}

Barker, D.H.N., and Austin, J.A., 1998, Rift propagation, detachment faulting, and associated magmatism in Bransfield Strait, Antarctic Peninsula: Journal of Geophysical Research, v. 103, p. 24,017-24,043.

Barker, P.F., 1982, The Cenozoic subduction history of the Pacific margin of the Antarctic PeninsulaRidge crest trench interactions: Geological Society of London Journal, v. 139, p. 787-801.

Barker, P.F., and Dalziel, I.W.D., 1983, Progress in geodynamics in the Scotia Arc region, in Ramon Cabré, S.J., ed., Geodynamics of the eastern Pacific region, Caribbean and Scotia Arcs: American Geophysical Union Geodynamics Series, v. 9, p. 137-170.

Barton, C.E., and 8 others, 1996, International geomagnetic reference field, 1995 revision: Geophysical Journal International, v. 125, p. 318-321.

Cande, S.C., and Kent, D.V., 1995, Revised calibration of the geomagnetic polarity timescale for the Late Cretaceous and Cenozoic: Journal of Geophysical Research, v. 100, p. 6093-6095.

Caress, D.W., and Chayes, D.N., 1996, Improved processing of Hydrosweep DS multibeam data on the R/V Maurice Ewing: Marine Geophysical Researches, v. 18, p. 631-650.

Hébert, H., Villemant, B., Deplus, C., and Diament, M., 1999, Contrasting geophysical and geochemical signatures of a volcano at the axis of the Wharton fossil ridge (N-E Indian Ocean): Geophysical Research Letters, v. 26, p. 1053-1056.

King, E.C., Leitchenkov, G., Galindo-Zaldivar, J., Maldonado, A., and Lodolo, E., 1997, Crustal structure and sedimentation in Powell Basin, in Barker, P.F., and Cooper, A.K., eds., Geology and seismic stratigraphy of the Antarctic margin, Part 2: American Geophysical Union, Antarctic Research Series, v. 71, p. 75-93.

LaBrecque, J.L., Kent, D.V., and Cande, S.C., 1977, Revised magnetic polarity time scale for Late Cretaceous and Cenozoic time: Geology, v. 5, p. 330-335.

Larson, R.L., and Chase, C.G., 1972, Late Mesozoic evolution of the western Pacific: Geological Society of America Bulletin, v. 83, p. 3627-3644.
Larter, R.D., and Barker, P.F., 1991, Effects of ridge crest trench interaction on Antarctic Phoenix spreading-Forces on a young subducting plate: Journal of Geophysical Research, v. 96, p. 19,583-19,607.

Lawver, L.A., Gahagan, L.M., and Coffin, M.F., 1992, The development of paleoseaways around Antarctica, in Kennett, J.P., and Warnke, D.A., eds., The Antarctic paleoenvironment: A perspective on global change: American Geophysical Union, Antarctic Research Series, v. 56, p. 7-30

Livermore, R., McAdoo, D., and Marks, K., 1994, Scotia Sea tectonics from high-resolution satellite gravity: Earth and Planetary Science Letters, v. 123 , p. $255-268$.

Luyendyk, B., Cisowski, S., Smith, C., Richard, S., and Kimbrough, D., 1996, Paleomagnetic study of the northern Ford Ranges, western Marie Byrd Land, West Antarctica: Motion between West and East Antarctica: Tectonics, v. 15, p. 122-141.

Macario, A., Haxby, W.F., Goff, J.A., Ryan, W.B.F., Cande, S.C., and Raymond, C.A., 1994, Flow line variations in abyssal hill morphology for the Antarctic Ridge at 65-Degrees-S: Journal of Geophysical Research, v. 99, p. 17,921-17,934.

Maldonado, A., Larter, R.D., and Aldaya, F., 1994, Fore-arc tectonic evolution of the South Shetland margin, Antarctic Peninsula: Tectonics, v. 13, p. $1345-1370$.

Maldonado, A., Balanya, J.C., Barnolas, A., GalindoZaldivar, J., Hernandez, J., Jabaloy, A., Livermore, R.A., Martinez, J.M., Rodriguez-Fernandez, J., Sanz de Galdeano, C., Somoza, L., Suriñach, E., and Viseras, C., 2000, Tectonics of an extinct ridge-transform intersection, Drake Passage (Antarctica): Marine Geophysical Researches (in press).

Mitchell, N.C., and Livermore, R.A., 1998, Spiess Ridge: An axial high on the slow spreading Southwest Indian Ridge: Journal of Geophysical Research, v. 103, p. 15,457-15,471.

Nakanishi, M., Tamaki, K., and Kobayashi, K., 1992, Magnetic anomaly lineations from Late Jurassic to Early Cretaceous in the west-central Pacific Ocean: Geophysical Journal International, v. 109, p. 701-719.

Nicholson, C., Sorlien, C.C., Atwater, T., Crowell, J.C., and Luyendyk, B.P., 1994, Microplate capture, rotation of the Western Transverse Ranges, and initiation of the San Andreas transform as a lowangle fault system: Geology, v. 22, p. 491-495.

Small, C., 1994, A global analysis of midocean ridge axial topography: Geophysical Journal International, v. 116, p. 64-84.

Smith, W.H.F., and Sandwell, D.T., 1994, Bathymetric prediction from dense satellite altimetry and sparse shipboard bathymetry: Journal of Geophysical Research, v. 99, p. 21,803-21,824.

Torta, J.M., GayaPique, L.R., Sole, J.G., Blanco, I., and Garcia, A., 1999, A new geomagnetic observatory at Livingston Island (South Shetland Islands): Implications for future regional magnetic surveys: Annali Di Geofisica, v. 42, p. 141-151.

Manuscript received October 18, 1999

Revised manuscript received March 22, 2000

Manuscript accepted April 4, 2000 